\title{
Factors Affecting the Selection of the Bariatric Surgeon-A Survey Study
}

\author{
Hüseyin Akyol MD', Berrin Erok MD²* \\ ${ }^{1}$ Department of General Surgery, Altınbas University School of Medicine Bahcelievler Medical Park Hospital, İstanbul, Turkey. ORCID: 0000-0001- \\ 5344-8894.
}

${ }^{2}$ Department of Radiology, Prof Dr Cemil Tascioglu City Hospital, İstanbul, Turkey. ORCID: 0000-0001-8036-547X.

*Corresponding Author: Berrin Erok, Department of Radiology, Prof Dr Cemil Tascioglu City Hospital, İstanbul, Turkey. ORCID: 00000001-8036-547X.

\section{Received Date: 23 August 2021 | Accepted Date: 29 October 2021 | Published Date: 01 December 2021}

Citation: H Akyol, B Erok. (2021). Factors Affecting the Selection of the Bariatric Surgeon-A Survey Study. International Journal of Clinical Case Reports and Reviews. 9(2); DOI:10.31579/2690-4861/172

Copyright: () 2021 Berrin Erok, This is an open-access article distributed under the terms of the Creative Commons Attribution License, which permits unrestricted use, distribution, and reproduction in any medium, provided the original author and source are credited.

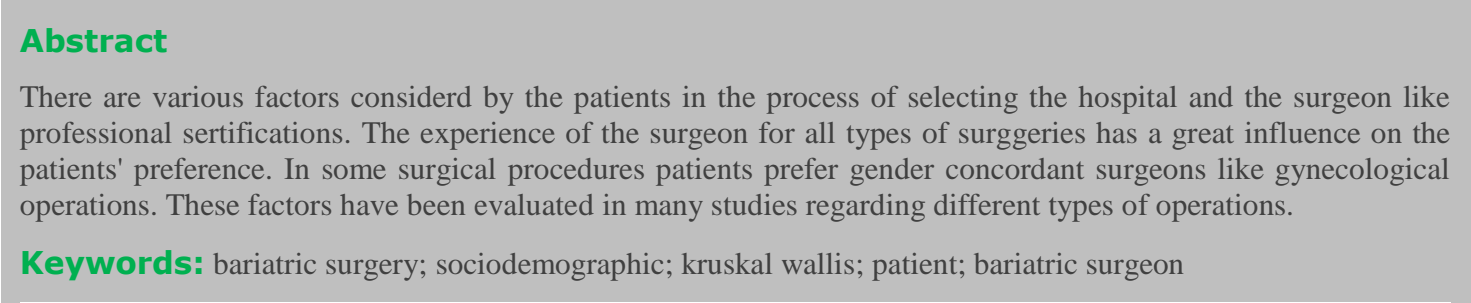

\section{Introduction}

There are various factors considerd by the patients in the process of selecting the hospital and the surgeon like professional sertifications [1]. The experience of the surgeon for all types of surggeries has a great influence on the patients' preference. In some surgical procedures patients prefer gender concordant surgeons like gynecological operations [2,3]. These factors have been evaluated in many studies regarding different types of operations. However, there is no such a research on the factors that the obesity patients consider when choosing their surgeon. Since the demand for bariatric surgery is increasing day by day, understanding the factors playing a role in the decision making process of these patients is important for both surgeons and hospitals. In this study we aimed to comprehensively determine the factors considered by the patients in selection fort he bariatric surgeon.

\section{Methods}

We developed a self administered online questionnaire by using Google survey platform. An introduction part informing the participants about the study's aim was added at the beginning of the survey. No financial rewards were given for completing the questionnaire. Ethical approval was obtained from our university's Institutional Ethical Board. The survey was designed to question the sociodemographic characteristics of the patients (table 1), the frequency of using social networks to obtain information (table 2) and the factors contributing to the bariatric surgeon selection process by the patients including the bariatric surgeon related factors and the hospital related factors (table 3,4 ). In addition, statements to finf out the patients' view on the contributing factors were included (table 5).

\begin{tabular}{|c|c|c|c|}
\hline & & Min-Max & Mean \pm SD \\
\hline age & & $18-57$ & $34,11 \pm 11,74$ \\
\hline $\begin{array}{l}\text { which doctor you consut about your illness is the doctor you will be } \\
\text { operated (median) }\end{array}$ & & $1-9$ & $2,04 \pm 1,74(1)$ \\
\hline & & n & $\%$ \\
\hline \multirow[t]{2}{*}{ age group } & <age of 40 & 34 & 63 \\
\hline & $\begin{array}{c}\text { age of } 40 \text { and } \\
\text { upper }\end{array}$ & 20 & 37 \\
\hline \multirow[t]{2}{*}{ Sex } & male & 27 & 50 \\
\hline & female & 27 & 50 \\
\hline \multirow[t]{4}{*}{ education level } & primary school & 9 & 16,7 \\
\hline & middle school & 11 & 20,4 \\
\hline & high school & 20 & 37 \\
\hline & university & 14 & 25,9 \\
\hline
\end{tabular}




\begin{tabular}{|c|c|c|c|}
\hline job group & working & 31 & 57,4 \\
\hline & housewifes & 15 & 27,8 \\
\hline & student & 8 & 14,8 \\
\hline income level & low & 5 & 9,3 \\
\hline & intermediate & 47 & 87 \\
\hline & high & 2 & 3,7 \\
\hline the frequency of using social media & yes & 45 & 83,3 \\
\hline & no & 9 & 16,7 \\
\hline
\end{tabular}

Table 1: Distribution of general features

\begin{tabular}{|c|c|c|c|c|c|}
\hline \multirow{2}{*}{$\begin{array}{c}\text { The social media networks that are used to obtain } \\
\text { infornation }\end{array}$} & Very rare & rare & sometimess & often & Very often \\
\hline & $\mathrm{n}(\%)$ & n $(\%)$ & n $(\%)$ & n $(\%)$ & n $(\%)$ \\
\hline web sites $(n=45)$ & $19(\% 42,2)$ & $1(\% 2,2)$ & $7(\% 15,6)$ & $12(\% 6,7)$ & $6(\% 13,3)$ \\
\hline facebook ( & $15(\% 33,3)$ & $5(\% 11,1)$ & $7(\% 15,6)$ & $11(\% 24,4)$ & $7(\% 15,6)$ \\
\hline instagram $(n=45)$ & $5(\% 11,1)$ & $1(\% 2,2)$ & $7(\% 15,6)$ & $19(\% 42,2$ & $13(\% 28,9)$ \\
\hline twitter $(n=45)$ & $20(\% 44,4)$ & $3(\% 6,7)$ & $8(\% 17,8)$ & $8(\% 17,8)$ & $6(\% 13,3)$ \\
\hline youtube $(n=45)$ & $11(\% 4,4)$ & $3(\% 6,7)$ & $14(\% 31,1)$ & $8(\% 17,8)$ & $9(\% 20)$ \\
\hline
\end{tabular}

Table 2: Distribution of the frequency of using social networks by those who use social media to obtain information

\begin{tabular}{|c|c|c|c|c|c|}
\hline & $\begin{array}{c}\text { not } \\
\text { imortant }\end{array}$ & $\begin{array}{c}\text { less } \\
\text { important }\end{array}$ & $\begin{array}{c}\text { moderately } \\
\text { important }\end{array}$ & important & $\begin{array}{c}\text { very } \\
\text { important }\end{array}$ \\
\hline & n (\%) & n $(\%)$ & n $(\%)$ & n (\%) & n $(\%)$ \\
\hline \multicolumn{6}{|l|}{ The doctor's fame } \\
\hline $\begin{array}{l}\text { The fact that the doctor is a famous, well known } \\
\text { person }\end{array}$ & $8(\% 14,8)$ & $1(\% 1,9)$ & $9(\% 16,7)$ & $\begin{array}{c}26 \\
(\% 48,1)\end{array}$ & $\begin{array}{c}10 \\
(\% 18,5)\end{array}$ \\
\hline $\begin{array}{l}\text { The advertisement related to the doctor } \\
\text { (tv/radio/nevspaper/ internet and sossial media) }\end{array}$ & $9(\% 16,7)$ & $4(\% 7,4)$ & $7(\% 13)$ & $20(\% 37)$ & $\begin{array}{c}14 \\
(\% 25,9) \\
\end{array}$ \\
\hline Being recommended by another doctor & $6(\% 11,1)$ & $4(\% 7,4)$ & $9(\% 16,7)$ & $\begin{array}{c}10 \\
(\% 18,5)\end{array}$ & $\begin{array}{c}25 \\
(\% 46,3)\end{array}$ \\
\hline Being recommended by family members and friends & $6(\% 11,1)$ & $4(\% 7,4)$ & $8(\% 14,8)$ & $\begin{array}{c}16 \\
(\% 29,6)\end{array}$ & $20(\% 37)$ \\
\hline $\begin{array}{l}\text { Being recommended by the former patients of the } \\
\text { doctor }\end{array}$ & $2(\% 3,7)$ & $2(\% 3,7)$ & $8(\% 14,8)$ & $\begin{array}{c}15 \\
(\% 27,8) \\
\end{array}$ & $27(\% 50)$ \\
\hline \multicolumn{6}{|l|}{ Attitudes of the doctor } \\
\hline Devoting enough time to the patient & $2(\% 3,7)$ & $1(\% 1,9)$ & $1(\% 1,9)$ & $\begin{array}{c}12 \\
(\% 22,2)\end{array}$ & $\begin{array}{c}38 \\
(\% 70,4)\end{array}$ \\
\hline Good communication skills & $2(\% 3,7)$ & - & $1(\% 1,9)$ & $\begin{array}{c}10 \\
(\% 18,5)\end{array}$ & $\begin{array}{c}41 \\
(\% 75,9)\end{array}$ \\
\hline Respecting to the ideas of the patient & $2(\% 3,7)$ & $2(\% 3,7)$ & $1(\% 1,9)$ & $\begin{array}{c}13 \\
(\% 24,1)\end{array}$ & $\begin{array}{c}36 \\
(\% 66,7)\end{array}$ \\
\hline Compansionate attitudes & $3(\% 5,6)$ & - & $5(\% 9,3)$ & $9(\% 16,7)$ & $\begin{array}{c}37 \\
(\% 68,5)\end{array}$ \\
\hline Smiling face & $1(\% 1,9)$ & $2(\% 3,7)$ & $2(\% 3,7)$ & $\begin{array}{c}11 \\
(\% 20,4)\end{array}$ & $\begin{array}{c}38 \\
(\% 70,4)\end{array}$ \\
\hline Giving importance to personal care and hygene & $3(\% 5,6)$ & $1(\% 1,9)$ & $5(\% 9,3)$ & $9(\% 16,7)$ & $\begin{array}{c}36 \\
(\% 66,7)\end{array}$ \\
\hline \multicolumn{6}{|l|}{ Features of the doctor } \\
\hline Age & $\begin{array}{c}22 \\
(\% 40,7)\end{array}$ & $6(\% 11,1)$ & $8(\% 14,8)$ & $\begin{array}{c}14 \\
(\% 25,9)\end{array}$ & $4(\% 7,4)$ \\
\hline How many years he/she has been a doctor & $6(\% 11,1)$ & $2(\% 3,7)$ & $10(\% 18,5)$ & $20(\% 37)$ & $\begin{array}{c}16 \\
(\% 29,6)\end{array}$ \\
\hline The school that he/she graduated & $\begin{array}{c}10 \\
(\% 18,5)\end{array}$ & $3(\% 5,6)$ & $13(\% 24,1)$ & $\begin{array}{c}17 \\
(\% 31,5)\end{array}$ & $\begin{array}{c}11 \\
(\% 20,4)\end{array}$ \\
\hline Having an abroad experience & $\begin{array}{c}10 \\
(\% 18,5)\end{array}$ & $\begin{array}{c}10 \\
(\% 18,5)\end{array}$ & $13(\% 24,1)$ & $\begin{array}{c}13 \\
(\% 24,1)\end{array}$ & $8(\% 14,8)$ \\
\hline Being a lecturer in a university & $8(\% 14,8)$ & $3(\% 5,6)$ & $18(\% 33,3)$ & $\begin{array}{c}15 \\
(\% 27,8)\end{array}$ & $\begin{array}{c}10 \\
(\% 18,5)\end{array}$ \\
\hline Having a surgical competency certificate & $2(\% 3,7)$ & - & $6(\% 11,1)$ & $\begin{array}{c}18 \\
(\% 33,3)\end{array}$ & $\begin{array}{c}28 \\
(\% 51,9)\end{array}$ \\
\hline Not being overweight (looking fit) & $\begin{array}{c}26 \\
(\% 48,1) \\
\end{array}$ & $4(\% 7,4)$ & $7(\% 13)$ & $\begin{array}{c}11 \\
(\% 20,4) \\
\end{array}$ & $6(\% 11,1)$ \\
\hline internet/social media & & & & & \\
\hline
\end{tabular}




\begin{tabular}{|c|c|c|c|c|c|}
\hline Having website by the doctor & $5(\% 9,3)$ & - & $6(\% 11,1)$ & $\begin{array}{c}29 \\
(\% 53,7)\end{array}$ & $\begin{array}{c}14 \\
(\% 25,9)\end{array}$ \\
\hline Having social media accouns by the doctor & $6(\% 11,1)$ & $1(\% 1,9)$ & $11(\% 20,4)$ & $\begin{array}{c}24 \\
(\% 44,4)\end{array}$ & $\begin{array}{c}12 \\
(\% 22,2)\end{array}$ \\
\hline Making informative posts on social media & $1(\% 1,9)$ & $1(\% 1,9)$ & $14(\% 25,9)$ & $\begin{array}{c}19 \\
(\% 35,2)\end{array}$ & $\begin{array}{c}19 \\
(\% 35,2)\end{array}$ \\
\hline Commets on the internet and social media & $2(\% 3,7)$ & - & $7(\% 13)$ & $20(\% 37)$ & $\begin{array}{c}25 \\
(\% 46,3)\end{array}$ \\
\hline
\end{tabular}

Table 3: Distribution of the level of importance given to the doctor related factors that are taken into consideration when choosing the doctor to operate

\begin{tabular}{|c|c|c|c|c|c|}
\hline & \begin{tabular}{|c|} 
not \\
important \\
\end{tabular} & $\begin{array}{c}\text { less } \\
\text { important }\end{array}$ & $\begin{array}{c}\text { moderately } \\
\text { important }\end{array}$ & important & $\begin{array}{c}\text { very } \\
\text { important }\end{array}$ \\
\hline & n $(\%)$ & n $(\%)$ & $\mathrm{n}(\%)$ & n (\%) & n $(\%)$ \\
\hline \multicolumn{6}{|l|}{ Other factors } \\
\hline $\begin{array}{c}\text { Presence of an aggreement of the doctor with an } \\
\text { insurance company }\end{array}$ & $\begin{array}{c}10 \\
(\% 18,5)\end{array}$ & $1(\% 1,9)$ & $6(\% 11,1)$ & $20(\% 37)$ & $\begin{array}{c}17 \\
(\% 31,5)\end{array}$ \\
\hline Easily getting an appointment & $1(\% 1,9)$ & $2(\% 3,7)$ & $3(\% 5,6)$ & $20(\% 37)$ & $\begin{array}{c}28 \\
(\% 51,9)\end{array}$ \\
\hline Not waiting for a long time fort he operation & - & $3(\% 5,6)$ & $5(\% 9,3)$ & $\begin{array}{c}15 \\
(\% 27,8)\end{array}$ & $\begin{array}{c}31 \\
(\% 57,4)\end{array}$ \\
\hline The hospital where the doctor works & $5(\% 9,3)$ & $2(\% 3,7)$ & $10(\% 18,5)$ & $\begin{array}{c}19 \\
(\% 35,2)\end{array}$ & $\begin{array}{c}18 \\
(\% 33,3)\end{array}$ \\
\hline The cheaper cost of the operation & $3(\% 5,6)$ & $3(\% 5,6)$ & $12(\% 22,2)$ & $\begin{array}{c}15 \\
(\% 27,8)\end{array}$ & $\begin{array}{c}21 \\
(\% 38,9)\end{array}$ \\
\hline being very elegance of the doctor's office & $7(\% 13)$ & $4(\% 7,4)$ & $18(\% 33,3)$ & $\begin{array}{c}14 \\
(\% 25,9)\end{array}$ & $\begin{array}{c}11 \\
(\% 20,4)\end{array}$ \\
\hline \multicolumn{6}{|l|}{ Hospital related factors } \\
\hline The hospital' being a famous, well known hospital & $4(\% 7,4)$ & $4(\% 7,4)$ & $10(\% 18,5)$ & $\begin{array}{c}24 \\
(\% 44,4)\end{array}$ & $\begin{array}{c}12 \\
(\% 22,2)\end{array}$ \\
\hline The atmosphere of the hospital & $2(\% 3,7)$ & $1(\% 1,9)$ & $6(\% 11,1)$ & $\begin{array}{c}29 \\
(\% 53,7)\end{array}$ & $\begin{array}{c}16 \\
(\% 29,6)\end{array}$ \\
\hline The hygene of the hospital & $2(\% 3,7)$ & $1(\% 1,9)$ & $6(\% 11,1)$ & $\begin{array}{c}10 \\
(\% 18,5)\end{array}$ & $\begin{array}{c}35 \\
(\% 64,8)\end{array}$ \\
\hline The hospital's being close & $1(\% 1,9)$ & $5(\% 9,3)$ & $13(\% 24,1)$ & $\begin{array}{c}17 \\
(\% 31,5)\end{array}$ & $\begin{array}{c}18 \\
(\% 33,3)\end{array}$ \\
\hline The hospital's working with an insurance & $2(\% 3,7)$ & $1(\% 1,9)$ & $9(\% 16,7)$ & $20(\% 37)$ & $\begin{array}{c}22 \\
(\% 40,7)\end{array}$ \\
\hline
\end{tabular}

Table 4: Distribution of the level of importance given to the other factors and the hospital related factors when chosing the doctor to be operated

\begin{tabular}{|c|c|c|c|c|c|}
\hline Indicate your degree of participitation in the & $\begin{array}{c}\text { I strongly } \\
\text { do not agree }\end{array}$ & $\begin{array}{c}\text { I do not } \\
\text { agree }\end{array}$ & occasionaly & I agree & $\begin{array}{c}\text { I strongly } \\
\text { agree }\end{array}$ \\
\cline { 2 - 5 } & $\mathbf{n}(\%)$ & $\mathbf{n}(\%)$ & $\mathbf{n}(\%)$ & $\mathbf{n}(\%)$ & $\mathbf{n}(\%)$ \\
\hline $\begin{array}{c}\text { the choice of the surgeon has an important effect } \\
\text { on the treatment process }\end{array}$ & $1(\% 1,9)$ & $2(\% 3,7)$ & $2(\% 3,7)$ & $17(\% 31,5)$ & $32(\% 59,3)$ \\
\hline $\begin{array}{c}\text { I have collceted information about the doctor } \\
\text { while making the choice. (internet, social media, } \\
\text { other hospitals })\end{array}$ & $4(\% 7,4)$ & $4(\% 7,4)$ & $8(\% 14,8)$ & $15(\% 27,8)$ & $23(\% 42,6)$ \\
\hline $\begin{array}{c}\text { the hospital where I will be operated is more } \\
\text { important than the doctor }\end{array}$ & $7(\% 13)$ & $17(\% 31,5)$ & $15(\% 27,8)$ & $10(\% 18,5)$ & $5(\% 9,3)$ \\
\hline $\begin{array}{c}\text { every docyor has a different treatment approach } \\
\text { I think it is important to get information about } \\
\text { the treatment methods before meeting with the } \\
\text { doctor }\end{array}$ & $2(\% 3,7)$ & $1(\% 1,9)$ & $12(\% 22,2)$ & $24(\% 44,4)$ & $15(\% 27,8)$ \\
\hline $\begin{array}{c}\text { I think it is important to get the opinions of the } \\
\text { other doctors before choosing the surgeon }\end{array}$ & $1(\% 1,9)$ & $4(\% 7,4)$ & $3(\% 5,6)$ & $31(\% 57,4)$ & $15(\% 27,8)$ \\
\hline the information I get from the internet is safe & $7(\% 13)$ & $11(\% 20,4)$ & $16(\% 29,6)$ & $15(\% 27,8)$ & $5(\% 9,3)$ \\
\hline $\begin{array}{c}\text { I think it will be beneficial to watch the surgery } \\
\text { videos about the surgery. }\end{array}$ & $6(\% 11,1)$ & $8(\% 14,8)$ & $14(\% 25,9)$ & $15(\% 27,8)$ & $11(\% 20,4)$ \\
\hline $\begin{array}{c}\text { I care about patients' experiences shared on } \\
\text { social media }\end{array}$ & $4(\% 7,4)$ & $2(\% 3,7)$ & $10(\% 18,5)$ & $27(\% 50)$ & $11(\% 20,4)$ \\
\hline
\end{tabular}




\section{Participants}

The questionnaire was sent to 134 patients who underwent bariatric surgery between 2016 and 2020. The fully filled questionnaires of 54 patients, of which $27(50 \%)$ male and 27 (50\%) female and aged between 18 and 57 were included in the study. The average age of the cases was $34.11 \pm 11.74$. The number of being the doctor to whom the patient consulted their disease ranges between 1 and 9 with average of $2.04 \pm 1.74$ and the median of 1 . While $63 \%$ of the cases are under the age of $40,37 \%$ of them are 40 years old and above. $16.7 \%$ were primary school graduates, $20.4 \%$ were middle school graduates, $37 \%$ were high school graduates and $25.9 \%$ were university graduates. $57.4 \%$ of the patients were working, while $27.8 \%$ were housewives and $14.8 \%$ are students. The income level was low in $9.3 \%$, moderate in $87 \%$ and high in $3.7 \%$ (table 1). While $83.3 \%$ used social media, $16.7 \%$ did not use social media. Among the cases using social media, \%13.3 was using web sites, \%15.6 facebook, $\% 28.9$ 'u instagram, 13.3 Twitter and \%20 Youtube'u to get information (table 2). The distribution of the other uses are as shown in the table 3,4,5.

\section{Statistical analysis}

When evaluating the findings obtained from the study IBM SPSS Statistics 22 (IBM SPSS, Turkey) program was used. The suitability of the study data to the normal distribution was evaluated by the Shapiro Wilks test. In addition to the descriptive statistical methods (mean, Standart deviation, frequency) in the comparison of the quantitative data Kruskal Wallis test was used in the comparison of parameteres that did not show normal distribution and Dunn's test was used fort he determination of the the group that caused the difference. In the two group comparison of the parameters that did not show normal distribution Mann Whitney U test was used. Statistical significance was determined as $\mathrm{p}<0.05$.

\section{Results}

The values of giving importance to the doctor related advertisements, social media accounts presence of the doctor, to be recommended by the former patients of the doctor and a website presence of the doctor were found to be statistically significantly higher among patients under the age of 40 years than those aged 40 and over [(p: 0.002; $<<0.05)$, (p:0.026; p<0.05, .(p:0.027; p<0.05, .(p:0.035; p<0.05); respectively].

The values of giving importance to informative posts of the doctor on social media and the comments made by the doctor on the internet and social media were found to be statistically significantly higher in men than women [(p:0.035; p<0.05), (p:0.022; $<<0.05)$; respectively].

There was a statistically significant difference between job groups of the patients in terms of the level of givinig importance to having a website ( $\mathrm{p}: 0.017 ; \mathrm{p}<0.05$ ). As a result of the paired comparison made to detect the difference, the level of giving importance by the housewifes was statistically significantly lower than those of the working patients and students ( $\left.\mathrm{p}_{1}: 0.048 ; \mathrm{p} 2: 0.005 ; \mathrm{p}<0.05\right)$. There was no statistically significant difference between the working patients and students $(\mathrm{p}>0.05)$.

There was a statistically significant difference between educational status of the patients in terms of the level of givinig importance to that the doctor is a famous, well known individual ( $\mathrm{p}: 0.003 ; \mathrm{p}<0.05)$. As a result of the paired comparison made to detect the difference, the level of giving importance by the primary school graduates was statistically significantly higher than those of the middle school and university graduates $\left(\mathrm{p}_{1}: 0.006\right.$; $\left.\mathrm{p}_{2}: 0.023 ; \mathrm{p}<0.05\right)$. The level of giving importance by the high school graduates was statistically significantly higher than those of the middle school and university graduates ( $\left.\mathrm{p}_{1}: 0.003 ; \mathrm{p}_{2}: 0.015 ; \mathrm{p}<0.05\right)$.

There was a statistically significant difference between job groups of the patients in terms of the level of givinig importance to that the doctor is a famous, well known individual (p:0.048; $\mathrm{p}<0.05)$. As a result of the paired comparison made to detect the difference, the level of giving importance by the students was statistically significantly higher than those of the working patients ( $\mathrm{p}: 0.030 ; \mathrm{p}<0.05)$. There was no statistically significant difference between the other job groups ( $p>0.05)$.

There was a statistically significant difference between educational status of the patients in terms of the level of givinig importance to that the hospital where the doctor works ( $\mathrm{p}: 0.036 ; \mathrm{p}<0.05)$. As a result of the paired comparison made to detect the difference, the level of giving importance by the primary school graduates was statistically significantly higher than those of the middle school and high school graduates $\left(\mathrm{p}_{1}: 0.047 ; \mathrm{p}_{2}: 0.008 ; \mathrm{p}<0.05\right)$.

There was a statistically significant difference between job groups of the patients in terms of the level of givinig importance to hospital hygene ( $\mathrm{p}: 0.026 ; \mathrm{p}<0.05)$. As a result of the paired comparison made to detect the difference, the level of giving importance by the housewifes was statistically significantly lower than those of the working patients and student groups ( $\left.\mathrm{p}_{1}: 0.015 ; \mathrm{p}_{2}: 0.028 ; \mathrm{p}<0.05\right)$.

There as a statistically significant difference between job groups of the patients in terms of the patients' level of participation in the statement 'I think it is important to get information about the treatment methods before meeting with the doctor', (p:0.005; $\mathrm{p}<0.05)$. As a result of the paired comparison made to detect the difference, was statistically significantly higher in working patients than in the housewifes and student groups (p:0.011; p:0.009; p<0.05).

\section{Discussion}

Obesity is a leading public health problem in developed and also developing countries. Obesity which has a significant negative influence on life expectancy increases the risk of many conditions as an independent factor like cancer [4,5]. It is also an independent poosr prognostic factor rot the current pandemic, tfe Covid-19 infection [6]. Bariatric surgery is increasingly considered by the patients who had unsuccesful results after trying to lose weight with traditional methods [7]. They consider several factors in the process of preferring their surgeons to be operated. Today, the information and communication technology plays an important role in our preferences and decisions in many aspects of our lives. Social media, which atracts great attention especially by young population is one of the important way that people benefit from in many decision making processes, even when making their holiday choices since the emergence of social media in 2004. It is known that individuals under the age of 40 pays more attention to social media and communication technologies. In our study, it is seen that the social media and web site presence of the surgeon was the most significantly contributing surgeon related factor for the bariatric surgeon selection especially in patients under the age of 40 years. When considering the gender, it is seen that informative posts and comments by the doctor on social media is significantly important for males. When considering the job, the prsence of websites of the doctor is sifnificantly important for working patients and students when compared with housewifes.

Advertisements about the doctor and being recommended by the former patients of the doctor are the other important factor especially for the patients under the age of 40 .

Amongst the hospital-related factors, hospital hygiene was found as the most significant hospital related factor in the bariatric surgeon selection and was significantly important for students and the working patients.

\section{Conclusion}

Our findings revealed that, obesity patients consider several factors in the process of preferring their surgeons to be operated, however our results particularly emphasize the importance of information technologies 
especially the effrct of social media in this decision making process. We believe that the results of our study is important in terms of showing the causal role that social media plays in obesity patients' consideration of bariatric surgery and selection of their surgeons.

Conflict of interest: none

Funding: none

\section{Author contributions:}

Concept: Hüseyin Akyol, Berrin Erok

Design: Hüseyin Akyol

Data: Berrin Erok, Hüseyin Akyol

Analysis: Berrin Erok, Hüseyin Akyol

Literature search: Berrin Erok, Hüseyin Akyol

Writting: Berrin Erok

Critical revision: Hüseyin Akyol, Berrin Erok

Acknowlegement: We thank to the participants for answering our online questionnaires.

\section{References}

1. Bornstein BH, Marcus D, Cassidy W. (2000). Choosing a doctor: an exploratory study of factors influencing patients' choice of a primary care doctor. J Eval Clin Pract. 6:255-262.

2. Plunkett B, Kohli P, Milad M. (2002). The importance of physician gender in the selection of an obstetrician or a gynecologist. Am J Obstet Gynecol. 186:926-928.

3. Schnatz P, Murphy J, O'Sullivan D, et al. (2007). Patient choice: comparing criteria for selecting an obstetrician-gynecologist based on image, gender, and professional attributes. Am J Obstet Gynecol. 197:548-548.

4. Segula D. (2014). Complications of obesity in adults: a short review of the literature. Malawi Med J. 26(1):20-24.

5. Chu Y, Yang J, Shi J. et al. (2020). Obesity is associated with increased severity of disease in COVID-19 pneumonia: a systematic review and meta-analysis. Eur J Med Res.

6. Wadden TA, Sternberg JA, Letizia KA, et al. (1989). Treatment of obesity by very low calorie diet, behavior therapy, and their combination: a five-year perspective. Int J Obes. 13:39-46.
This work is licensed under Creative Commons Attribution 4.0 License

To Submit Your Article Click Here: Submit Manuscript
Ready to submit your research? Choose Auctores and benefit from:

$>$ fast, convenient online submission

$>$ rigorous peer review by experienced research in your field

$>$ rapid publication on acceptance

$>$ authors retain copyrights

$>$ unique DOI for all articles

$>$ immediate, unrestricted online access

At Auctores, research is always in progress.

Learn more auctoresonline.org/journals/international-journal-of-clinicalcase-reports-and-reviews 